\title{
KANT ON CIVILIZATION, MORALIZATION, AND THE PARADOX OF HAPPINESS
}

\author{
Sergio Cremaschi
}

\section{Kant on happiness}

Kant is often thought to hold that happiness is not valuable, and even to have ignored it wholly in his ethics. This is a serious mistake. It is true that for Kant moral worth is the supreme good, but by itself it is not the perfect or complete good. To be virtuous, for Kant, is to be worthy of happiness, and the perfect good requires that happiness be distributed in accordance with virtue [....] Happiness, or the sum of satisfaction of desires, is a conditional good. It is good only if it results form the satisfaction of morally permissible desires. But it is intrinsically valuable nonetheless: It is valued by a rational agent for itself, and not instrumentally ${ }^{1}$.

This assessment by a recent influential interpreter turns two centuries misunderstanding upside down; in fact Kant was not the proponent of a "grumpy" morality, which he thought indeed to be mistaken", but only meant to avoid its opposite, an "enticing" morality that would try to persuade to virtuous conduct through promises of happiness as a reward to virtue, which he believed to be a corruption of genuine morality.

Kant's polemics against eudemonism is well-known, but also overstressed. In fact, he wanted to avoid doctrines corrupting the true principles of morality, or the simple reasons for acting that the conscience, or heart, of any plain man is able to perceive easily enough. But a desire of being happy was for him natural, and strong enough not to require any doctrine that would prompt us to pursue happiness as a duty. But he had it clear in mind that, once we leave the point of view of the individual agent and adopt the point of view of God, the maximum amount of happiness in the world is the highest end, once the proviso is added that this should come with merit or should be happiness with virtue.

Kant's definition of happiness is far from univocal. He talks of Glücklichkeit or Glücksgaben while indicating external goods, such as "power, wealth, honour, and even health and the overall satisfaction and contentment with one's state"3. His highest good is presented as something different from happiness, indeed as a sum of happiness and virtue. Thus he tends to underrate the plausibility of the views proposed by ancient philosophers, even if he is quite uncertain, being occasionally appreciative even of Epicurus whom he condemns in most places as the proponent of a mistaken doctrine, and even if closer to the Stoics, he criticizes them for forgetting the sensuous side of human nature, and is finally quite uncertain about Aristotle himself ${ }^{4}$.

\section{Kant and political economy}

The name of Kant hardly shows up in any history of economic thought, and yet Kant, who taught as different subjects as physical geography and military engineering and had a remarkable competence in chemistry, was not totally unaware of what had been going on in this field during the eighteenth century. In the Lectures on physical geography he makes room for a mercantile geography which accounts for the ways in which different countries are naturally led to specializing in production of different commodities, and then how commerce ties up different nations with the bounds of commerce, which are bounds of friendship and pave the way toward a cosmopolitan society ${ }^{5}$.

He had read in the Seventies The Theory of Moral Sentiments in the German translation based on the second edition and Smithian concepts as sympathy and the impartial spectator are not 
unfamiliar to Kant, even if he seems to have in mind more his contemporary German proponents of a doctrine of moral sentiments. By the time he published the Metaphysics of Morals, he was aware also of the contents of The Wealth of Nations (that had been translated into German in the meanwhile) and referred approvingly to Adam Smith's definition of money:

Money is therefore (according to Adam Smith) that material thing the alienation of which is the means and at the same time the measure of the industry by which human beings and nations carry on trade with one another"- This definition brings the empirical concept of money to an intellectual concept by looking only to the form of what each party provides in return for the other" 6

And, thus, provides a dogmatic definition a priori of money, "which is appropriate to the metaphysics of right as a system"7. Besides, in his writings on the philosophy of history he shows the same keen awareness of the civilising function of commerce as the Scottish philosophers, and particularly Adam Smith, and tries to locate it within the context of a complex dialectic between civilisation and moralisation.

And yet, a few decades afterwards, Kant had become a banner in the hands of German opponents of the 'English' greedy philosophy of Manchesterismus, named also Smithianismus or finally Utilitarismus, all of them identified with the selfish system of Mandeville, supposedly the spokesman of the capitalist spirit. All this would be of merely antiquarian interest, if it had not left some die-hard traces in Continental philosophical culture. Instead, Kant the moral and political philosopher tried to deal with basically with the same problem as Adam Smith, namely how growth of wealth and civilisation on the one hand, and of liberty and morality on the other may be made not only compatible, but also interdependent.

\section{Kant's impure practical reason}

Kant's contribution to economic discourse has not been, to say the least, very popular. One reason for that is that Kant's fragmentary contributions fit in a part of his oeuvre that fell into oblivion for a number of reasons, such as that of having being published in the Nineties, that is once the discussion had already become hot about Kant's alleged ethical formalism as illustrated in the works of the Eighties, or not fitting the cliché created by romantic critic of the Enlightenment. This part is the "doctrine of prudence", or "moral anthropology", or "practical anthropology", or "pragmatic anthropology" or "empirical moral philosophy" 8 (and, at the very beginning of his intellectual career, "moral geography") $)^{9}$. The very plurality of names for the subject is telling: this part of Kant's philosophy is, more than a sub-discipline, a crossroad or a joint, namely the discussion of the aspect for which human beings are both parts of the kingdom of freedom and of the kingdom of nature ${ }^{10}$. Indeed, it is one side of rational ethics, but also a part of "cosmological knowledge" together with "physical geography", and it discloses us the sources of "all the sciences, morals, technology, social customs, the method for educating and governing human beings, and accordingly of the practical sphere as a whole"11. The very variety of descriptions of the would-be discipline is telling. Kant had been struggling during all is life with the status of this sub-discipline, a source of trouble but also, or precisely for the same reason, the unsuspected kernel of his philosophical oeuvre.

Pragmatic anthropology, if we agree to call it by its latest name, is a description of the ways in which moral sentiments and the faculty of moral judgement may develop in the individual as well as in mankind. It is in a sense the only 'practical' part of ethics qua ethical theory. If we adopt stricter criteria, practical ethics is ethics put into practice, not a doctrine, but instead a skill. If we adopt looser criteria, pure normative ethics cannot be applied to individual cases, where we are left with the faculty of judgement, and is limited to making explicit to us the reasons we have for 
acting according to the moral law, and only anthropology is "practical", albeit in a limited sense, in so far as it provides strategies for education and policies for fostering the development of civilisation.

I said that Kant's real "practical" ethics is not a discipline, but instead an activity, what Moses Mendelssohn in the Sixties had labelled "the practical [Ausübende] doctrine of morals"12. As Kant objected to Christian Garve in the Nineties, in the individual case it is the faculty of judgement, not a set of abstract principles, that handles the individual case and solves moral dilemmas ${ }^{13}$.

The reader may argue that room is left also for empirical/theoretical social sciences, ones that be based on causal explanations instead of "observations", and that may explain social phenomena as if they were natural phenomena, governed by necessary laws. In fact, "human actions", as phenomena corresponding to a noumenal entity that is free will, that is, when considered as if they were empirical, or causally determined, facts, are nonetheless "determined in accordance with universal laws of nature, as is every other natural event"14. Thus, Kant's would-be empirical social sciences would be sciences neither value-free nor immediately subordinate to ethics, since the mentioned twofold teleology of ends allows for a system of "pragmatic" ends, aiming at the subjective end of happiness as individuals are able to represent it to themselves, and to the objective end of the full development of mankind's potentialities, which is in turn connected with a moral end, the development of mankind's full moral powers ${ }^{15}$.

There are indeed, according to Kant, law-like connections among those ends, that may be made the subject of study in themselves, not unlike Kepler who discovered the thread of natural phenomena, and Newton who discovered the hidden cause governing that thread, even if we are still waiting for a Newton of societal laws. Thus, the social sciences are neither immediately moralized sciences (as German nineteenth-century alleged followers of Kant, and, later on, a number of Catholic social thinkers claimed), and yet they have some inherent link to the higher moral ends through the twofold immanent in human action ${ }^{16}$.

\section{Kant on the paradox of Happiness}

Let us come back to Kant and happiness, ruled out as a source of ethical standards on the one hand, and construed as an intrinsic value on the other, and let us try to make sense of what Kant says on the basis of the picture drawn in the two above sections.

Kant was an avowed ethical rigorist, in the sense that he believed that moral reasons may only be presented in their purity, qua rational reasons, if they are to have any motivating force. But rigorism does not entail logically also ascetism, hate for pleasure, for the passions, and for sociability. This is instead the main content of Kantian mythology.

It is true that the reader of the Foundations of the metaphysics of Morals may have the impression that morality be tantamount to reason, as contrasted with "inclination" or self-love, and that the eventual source of moral evil is sensuousness. But, apart from serious troubles that may be detected in Kant's view of self-love and prudence ${ }^{17}$, it is fair reminding that Kant's main concern in this work was ruling out happiness as a possible ground for morality, indeed ruling out the current idea of happiness as a pseudo-concept in so far as happiness be understood as a pleasure which be constant through time, as "the condition of a rational being in the world, to whom in his existence as a whole everything happens according to his wish and will"18.

But moral law contains no idea of any necessary connection between morality and happiness, since the moral law is not a law of causal connections in the world, those connections whose control is the staple of any possible happiness, since "the acting rational being in the world is not in the meantime the cause of the world and of nature itself"19. It is true that the quest for 
happiness is a duty, but in a special sense: as a kind of indirect duty, since a state of need as is carried by poverty may prompt us to violate the moral law ${ }^{20}$.

But there is some other state that cannot be identified with happiness as it is commonly understood, and which provides instead an example of an unconditionally desirable state. As early as in the Sixties an Seventies, in the Reflexionen Kant mentions Selbstzufriedenheit as an intermediate link between virtue and happiness, since it is at once an effect of virtue as well as an autonomous source of happiness; the quest for pleasure is an expression of dependence, while self-contentment (still understood in a Leibnizian mood as contemplation of one's own growth in perfection) is an expression of autonomy ${ }^{21}$. In the eighties, leaving the Leibnizian theme of perfection somewhat aside, Kant singles out the source of pleasure in the feeling of autonomy or freedom from causal determination. Self-contentment is "a feeling of pleasure or of well-being in the accomplishment of duty that implies a causal power of reason in determining sensuousness in conformity to its own principles" 22 , awareness of one's freedom in terms of independence from inclinations, and thus "unshakable contentment that is of necessity linked with such awareness, that does not rest on any particular sentiment and deserves to be qualified as intellectual" 23 . Nature itself seems to have conceived as her own end for man a "rational self-esteem" more than welfare, and even when man reaches as much happiness as is possible as is possible in this world, Nature's design is apparently "that he may reach it by his own efforts, and thus to have an opportunity to be grateful to himself" 24 .

In so far as somebody who acts according to morality is not under the constraint of external causal powers, such as inclination or self-love, that is always an empirical cause, he is free: a "good will", that is "the indispensable condition for deserving to be happy"24. Only the one who is master of virtue is "free, healthy, wealthy, a king", since only the one who is master of virtue "is master of himself" 25 .

Kant had already been clear in his Lectures on Moral Philosophy about two opposing mistakes into which ethics may fall: the former is the one of becoming a kind of "enticing ethics" that endeavours to persuade the audience of the eventual convergence between virtue and happiness, the other is that of becoming a kind of "grumpy ethics", that opposes morality to the joys of life; it is true that "if one had to allow for one mistake in ethics, it would be better to allow for the mistake of rough ethics", since it originates from concern with preserving the purity of moral principles, but it is nonetheless a mistake, since the source of evil does not lie in inclinations, but instead in the "perversity of the heart" ${ }^{26}$. Kant always disapproved of ascetic kinds of morality. In the Lectures he said that "fanatical moralists" believe that mastery over the body is conquered by means of prohibiting everything that "gives sensuous satisfaction to the body", but that practices of such a kind are monkish and fanatical virtues "27. Instead, the body should be cared for, even if avoiding any excess ${ }^{28}$, and pleasures may be recommended as far as they have a socializing function: drinking is not as bad as eating too much, and banquets bring about "besides a purely physical pleasure, something which tends toward a moral end, namely bringing together several people and entertaining them for a while in mutual intercourse"29.

Happiness is still a problem, even if we cease looking at it in the mistaken light of a "right to happiness" as most eighteenth-century thinkers $\mathrm{did}^{30}$. It makes a problem once it is seen as the problem of the "summum bonum", namely of the concomitance of virtue and happiness. The happiness of the just man is something that we have to wish for rational, not empirical reasons, and what we may wish to be both happy and deserving happiness (note that Adam Smith makes the same point).

The problem of theodicy, that is Leibniz's and Bayle's question about the possibility of reconciling the existence of a benevolent Creator with lack of correspondence between virtue and happiness, 
admits of no answer, as Voltaire and Adam Smith had argued ${ }^{31}$, and Kant reaches the same conclusion $^{32}$.

But for Kant happiness-with-virtue needs to be brought about, and the Stoics were mistaken, in so far as, even if they "were right in had choosing virtue as a condition for the Summum Bonum", yet, "not including also happiness into it had denied the sensuous aspect of human nature". Kant resolves the antinomies he had left open through a natural theology based on ethics as its starting-point and thus introduces the idea of God and an after-life $\mathrm{e}^{33}$.

\section{Deception and unintended results}

But it is a desirable ting that truths about the final destination of man may be apprehended just as postulates, as consequences, not pre-conditions of morality, since, had we been certain about the existence of an after-life, our actions would have as free as those of "puppets"; in a word, we have to be thankful to the divine wisdom for "what was left hidden to our eyes as much as for what was revealed" 34 .

Thus, limits to knowledge and deception in knowledge are not only the tools by which self-love in drag manipulates human beings, but also a fundamental condition of human life, of action, civilisation, and finally of the process of moralisation. Kant had learned from the sceptics and the Jansenists that transparency of consciousness is a delusion, that we may always detect, behind actions conforming to duty, disguised self-love ore "the beloved self ${ }^{35}$, for "the depth of man's heart is inscrutable" ${ }^{36}$. We cannot judge the actions we have carried out; what we can do is just fixing maxims for our prospective actions. The enemy virtue has to fight is not the passions, as the Stoics used to believe, since the passions are something natural, but is instead an invisible enemy, the perversity of human heart that "through principles corrupting the soul, secretly undermines the original intention itself" 37 .

Deception plays a basic role in the history of mankind, in so far as it allows for a hidden twofold teleology of human action; in fact, human beings, while following the dictates of self-love, pursue such delusory ends as welfare, wealth and power or, in a word, happiness, and put to work and indeed improve their reason, both in its theoretical and in its technical aspects, as a means for attaining those ends. But human beings are systematically mistaken about the results they do contribute in bringing about, firstly because happiness is a self-contradictory goal, secondly because individual human life is too short for men to enjoy the results of their efforts, thirdly because the unintended result of the interaction between the individuals' anti-social drives is a system of rights and regulations. The final result is a growth of enlightenment, learning, education, and freedom, and this prepares the condition for full development of the moral capacities men are endowed with. To sum up: human action is lead by "subjective" ends and, in the meanwhile, by ends pursued by nature through unintended results.

Deception is also an unavoidable requirement of virtue: civilisation carries politeness, and the latter carries the custom of feigning feelings of benevolence and respect for each other, even if there is no true sincere intention behind them. This does not amount to deceiving each other, since everybody knows that sincerity is never at home in worldly life, and politeness and civility provide at least a coat for instincts, a coat that may protect a room where the growth of true virtue may take place ${ }^{38}$.

Let me recall that the claim that limited knowledge is a pre-condition for morality is central for Adam Smith as well in his critique of the Stoics and Cambridge Platonists ${ }^{39}$. Also the idea of deception as a basic component of our knowledge of nature, of morality, and of social life is a central point of Adam Smith's system of ideas and a point where Kant meets Adam Smith's train of thought ${ }^{40}$. 


\section{Civilisation or Moralisation}

There is a well-known passage in the Foundations of the Metaphysics of Morals that has left commentators somehow puzzled. There Kant states that in

the natural dispositions of an organised, i.e. teleologically adapted for life, being, we assume as an axiom that we will never find in it any tool for whatsoever goal that be not also the most effective and adequate for such goal. If the Nature's only goal for a being that has reason and a will were its preservation, its welfare, in a word its happiness, then it would have ill-conceived its design by choosing the reason of such a creature as the executor of the mentioned plan. Since all actions that it has to carry out with a view at this goal and the overall pattern of its behaviour would be much more precisely indicated to it by instinct ${ }^{41}$.

As a consequence, some (read: Rousseau and his followers) are right in believing that civilisation is useless as a means to happiness, and that if Nature's real goal had been the happiness of rational beings, it would have been much better leaving such an end to the care of something more reliable, such as instinct is. It is because of the observation we may constantly do that "in so far as a cultivated reason dedicates itself to the perspective of enjoyment of life and happiness, to the same extent the human being departs himself from true contentment ${ }^{\prime \prime 2}$ that misology, or hatred against reason, has arisen.

This passage starts making fuller sense when located within the framework of Kant's writings on philosophy of history, where he contrasts civilisation with moralisation as two different phases in the growth of mankind. In this context, the growth of commerce and manufactures plays a distinctive role, namely that of means of fostering civilization, even if all human efforts in this direction are prompted by the image of a deceptive goal, happiness.

Because of the opacity of consciousness, Kant believes that "judgment" (a nearly-Aristotelian category that he believes to have the last word on individual prospective actions) be almost impossible about actions, both by ourselves and others, once they have been carried out, since "real" intentions cannot be detected. Instead, some kind of reflective judgment, of the kind he depicts in the Critique of Judgment, is quite practicable on the process of moral development. This means that we may look at the history of mankind as if it were a process of moral development not unlike the individual development described in Rousseau's Émile, and the good reason we have for believing that the agenda of human history is in fact a path to moralization is a moral necessity of believing in the possibility that morality may come fully into reality.

Nature prompts men to undertake every kind of effort in order to obtain more comfort, wealth, safety, in a word more happiness. Most of the time, the individual will not enjoy the results of his efforts but will leave them instead to his offspring. Besides, self-love and unsociability bring people into mutual interaction, through war and conquest, and later on through less offensive activities, such as commerce; commerce brings different peoples into mutual relationship and thus paves the way to a cosmopolitan society. Finally, the growth of the arts and sciences provides preconditions for the birth of learned institutions, a free press, and a public opinion that are the basis for use of reason in its critical capacities.

The process described, that is civilisation, carrying Enlightenment, is a preliminary step to moralisation, that is the rise of individuals from a state of minority to a state where they become their own masters. Kant writes:

Civil liberty cannot any more be really impaired unless every kind of activities, most of all commerce be seriously injured [...] If one hinders the citizen from looking after his own welfare in whatever manner he likes, provided that it may coexists with other people's freedom, he impairs vitality of industry as a whole [...] as a consequence 
limitations to the individual will be gradually reduced, universal religious freedom will be promoted; and, albeit mixed up with chimeras and extravagant fancies, Enlightenment will be gradually brought about ${ }^{43}$.

\section{The quest for Happiness and the conquest of virtue}

It may be fruitful to compare the misology passage with another in the writings on the philosophy of history where Kant states that, until the final goal of human history, namely a cosmopolitan federation of states, be attained, mankind shall suffer every kind of evil

under the delusive cover of external welfare; and, thus, Rousseau was right in preferring the state of savages, if one does not consider the last stage to which our kind still has to raise itself. By means of art and science, we are cultured to a high degree. We are civilised, even too much, in every kind of courtesy and social decorum. But we are still far from being moralised ${ }^{44}$.

Both passages may be compared in turn with a well-known passage by Adam Smith in The Theory of Moral Sentiments, where the same Rousseauvian theme is developed in order to show how wealth is useless for promoting happiness, and is pursued for the sake of imaginary ends, eventually prompted by the mechanism of sympathy that makes so that we desire to be envied and honoured by our fellows. Adam Smith adds that deception plays an unavoidable, and even useful, function in fostering the growth of commerce, the arts and sciences, and thus of civilisation; indeed it is "what first prompted him to cultivate the ground, to build houses, to found towns and republics, to invent and improve all the sciences and the arts" ${ }^{45}$. This eventually makes a free and peaceful society possible, one based, if not on "perfect equality, perfect justice, and perfect liberty", at least on some second best ${ }^{46}$. The semi-sceptical and semi-pessimistic considerations by Adam Smith in 1790 on the "wise man" (to be contrasted with the prudent man) and his public spirit ${ }^{47}$, make sense when viewed at within the framework of a dialectic between happiness, growth of opulence, moral losses as well as new opportunities for equality and dignity carried by this growth ${ }^{48}$.

Also Kant's philosophy of history is based on a similar dialectic: the quest for a delusory happiness is a spring of action, and it is self-love that prompts activity in order to dominate others, but the unintended results of a sum of such actions is a development of a system of civilised states under the rule of law and finally - at least we may bet - of a cosmopolitan society. Such a path to be followed by human history is just a possibility; there is no science of the laws of historical development; we are left with a moral postulate that allows for a view of human history in terms of a route to moralisation. The quest for happiness plays the role a link between self-love and morality, and all the development of technique, geographical discoveries, and war first and commerce at a later stage, and then of manufactures, and of the arts and sciences, is for Kant no less than for Adam Smith a machine, one too complicated complex and with too many side-effects for being considered to be an efficient means to its 'subjective' end, i.e. happiness ${ }^{49}$. But this complex combination of causes and effects is not too complex if viewed at as a route toward human improvement. And this makes morality (or recovery of an original state of innocence) possible, while leaving human beings as disillusioned as ever about "happiness" 50 , unless the summum bonum, that is a state that includes both moral and non moral elements, were finally taken by human beings as the true goal for action, instead of "happiness".

10. Conclusions: the quest for happiness, economics, and morality

To sum up: 
i) Kant was aware, following the heritage of Hellenistic ethics and of its Renaissance revival, that wealth is a very poor means to happiness,

ii) He added a more sophisticated claim, namely that the very idea of 'happiness', as understood in the eighteenth century, was a contradictory idea; he was not fully aware of the comparative sophistication of Aristotle's idea of eudaimonia, and indeed he tended to mistake it for the eighteenth-century idea of happiness; his own idea of highest good (a good where material well-being and moral worth are joined together) was closer to Aristotle's eudaimonia than his own idea of Glücklichkeit;

iii) he had also learned the lesson of the sceptics and Jansenists, that men are led by deceptive ends;

iv) and he was aware, more than any other enlightener, that human actions are also empirical phenomena that may be explained on the basis of laws like the universal laws of Nature of the new Galilean and Newtonian science;

v) his 'real' idea of happiness is the idea of a state where man is both happy and deserving happiness, that is the summum bonum; a state that includes both moral and non moral elements, not unlike Aristotle's eudaimonia, that he probably never appreciated properly;

vi) a second best for the summum bonum is, on the one hand, "contentment", deriving from awareness of not having purposively violated the moral law as well as from awareness of having done the best to develop the gifts of humanity in oneself;

vii) on the other hand, another second best is "a morally valid happiness"; indeed the Stoics were mistaken in forgetting that man is both rational and sensible, and the second best that may be pursued on earth results from a sum of virtue with some amount of welfare, within the limits of civilisation and sociability; pace the cynics and the anachoritis, Kant's second best number two is "a good meal in a good company"51; this is an expression of a "morally valid happiness" and rules of human refinement, so far as they help social intercourse, "are a coating that helps virtue" and ascetic virtues are "degenerated forms of virtue which do not encourage the practice thereof; once abandoned by the Graces, that cannot advance claims to humanity" 52 ;

viii) The standard German nineteenth-century opposition notwithstanding, the kind of problems Kant faced were the same problems Adam Smith had faced; an important number of claims was shared, concerning civilisation, the vanity of wealth, deception, and partly the nature of happiness; but, ironically, Kant, the alleged rigorist moral philosopher, had a more positive view of material satisfaction than Adam Smith, the alleged founder of the greedy doctrine of selfinterest.

\section{Bibliography}

In the footnotes, the first page number refers to the original, the second to the English translation.

Bruni, F., 1987. 'La nozione di lavoro in Adam Smith'. Rivista di filosofia neoscolastica 79\1, pp. 6795.

Cremaschi, S., 1984. Il sistema della ricchezza. Economia politica e problema del metodo in Adam Smith, Milano: Angeli.

Cremaschi. S., 1989. Adam Smith. Sceptical Newtonianism, Disenchanted Republicanism, and the Birth of Social Science, in M. Dascal, O. Gruengard eds, Knowledge and Politics: Case Studies on the Relationship between Epistemology and Political Philosophy, Boulder (Co): Westview Press: 83110. 
Cremaschi, S. 1998. Homo oeconomicus, in H.D. Kurz, N. Salvadori eds, The Elgar Companion to Classical Economics, Cheltenham: Elgar, pp. 377-381.

Cremaschi, S. 2002a. 'Two views of Natural Law and the Shaping of Political Economy', Croatian Journal of Philosophy 2\5, pp. 65-80.

Cremaschi, S., 2002b. Adam Smith's Economic Ethics and Social Theodicy, Paper presented at the 2002 ESHET Annual Meeting, Rethymnon, March 2002.

Cremaschi, S., 2003a. The Absence of Homo Oeconomicus in Adam Smith. Paper presented at the 2003 ESHET Annual Meeting, Paris, January 2003.

Cremaschi 2003b: Kant's empirical moral philosophy, in B. Bercić, N. Smokrović, Proceedings of Rijeka Conference "Knowledge, Existence and Action", Hrvatsko drustvo za analiticku filozofiju Filozofski fakultet Rijeka, Rijeka 2003, pp. 21-24.

Engstrom, S., Happiness and the Highest Good in Aristotle and Kant, in S. Engstrom, J. Whiting eds, Aristotle, Kant, and the Stoics, Cambridge: CUP, 1996, pp. 102-138.

De Luise, F. and G. Farinetti, 2001. Storia della felicità. Gli antichi e i moderni. Torino: Einaudi.

M. Foucault, 1964. Notice historique, in I. Kant, Anthropologie du point de vue pragmatique, Paris: Vrin, 1970.

Irwin, T. H., Kant's Criticism of Eudaimonism, in S. Engstrom, J. Whiting ed., Aristotle, Kant, and the Stoics, Cambridge: CUP, 1996, pp. 63-101.

Hill, T.E. Jr., 1999, 'Happiness and Human Flourishing in Kant's Ethics'. Social Philosophy and Policy 16\1: 143-175.

Hirschman, A.O., 1977, The Passions and the Interests, Princeton: Princeton University Press.

Manganaro, P., 1983. L'antropologia di Kant, Napoli: Guida.

Kant, I. [Ak] Kant's Schriften. Ed. Berlin-Brandenburgischen Akademie der Wissenschaften, Berlin, Meiner-De Gruyter, 1902-.

Kant, I. 1773. An Marcus Herz. In Ak, X.

Kant [R] Reflexionen. In Ak XV.

Kant, I. [MC] Moralphilosophie Collins. In Ak, XXVII \1.

Kant MM: Moral Mongrovius I, in Ak, vol. XXVII 2,2, pp. 1395-1581.

Kant, I. [PPP] Praktische Philosophie Powalski. In Ak, XXVII $\backslash 1$.

Kant, I. [MSV] Metaphysik der Sitten Vigilantius. In Ak, XXVII2,1

Kant, I. 1784. Idee zu einer allgemeine Geschichte in weltbürgerlicher Absicht. In Ak IV; Engl. transl. Idea for a Universal History with a Cosmopolitan Purpose. In Kant, Political Writings, ed. H. Reiss, Cambridge: Cambridge University Press, 1991 (2 ${ }^{\text {nd }}$ ed.), pp. 41-53.

Kant, I., 1785. Grundlegung der Metaphysik der Sitten. In Ak IV; Engl. transl. Groundwork of the Metaphysics of Morals, ed. M. Gregor and Ch.M. Korsgaard, Cambridge: Cambridge University Press, 1998

I Kant, 1788. Kritik der praktischen Vernunft. In Ak, V; Engl. transl. Critique of Practical Reason, Cambridge: Cambridge University Press, 1997.

I. Kant, 1791. Über das Misslingen aller philosophischen Versuche in der Theodicee. In Ak VIII.

Kant, I., 1793. Über den Gemeinspruch: Das Mag in der Theorie richtig sein, taugt aber nich für die Praxis, in Ak VI; Engl. transl. On the Common Saying: "This may be True in Theory, but does not Apply to Practice". In Kant, Political Writings, ed. H. Reiss, Cambridge: Cambridge University Press, 1991 ( $2^{\text {nd }}$ ed.), pp. 61-87.

Kant, I., 1797. Metaphysik der Sitten. In Ak VI; Engl. transl. The Metaphysics of Morals, ed. M. Gregor and R.J. Sullivan, Cambridge: Cambridge University Press, 1996.

Kant, 1798, Anthropologie in pragmatischer Sicht. In Ak VI. 
Kant, I. 1799. Die Religion innerhalb der grenzen der blossen Vernunft. In Ak VI; Engl. transl. Religion within the Boundaries of Mere Reason, ed. A. Wood and others, Cambridge: Cambridge University Press, 1998.

Kant, I., 1802. Physische Geographie. In Ak IX.

Mendelssohn, M. 1764. Abhandlung über die Evidenz in metaphysischen Wissenschaften, in Gesammelte Schriften. Jubiläumausgabe, 22 voll., Stuttgart - Bad Cannstatt, Fromann, 1971-1995, vol. II.

Pleines, J.-E. 1984. Eudaimonia zwischen Kant und Aristoteles. Glückseligkeit als höchstes Gut menschlichen Handelns, Würzburg: Königshausen - Neumann.

Schneewind, J.B., Autonomy, Obligation, and Virtue. An Overview of Kant's Moral Philosophy, in P. Guyer ed., The Cambridge Companion to Kant, Cambridge: C.U.P., 1992, pp. 309-341.

Scuccimarra, L. 1997, Kant e il diritto alla felicità, Roma: Editori Riuniti, Smith, A. [1759] 1976, The Theory of Moral Sentiments, Clarendon Press, Oxford.

Smith, A. [1776] 1976, An Inquiry into the Nature and Causes of the Wealth of Nations, Clarendon Press, Oxford.

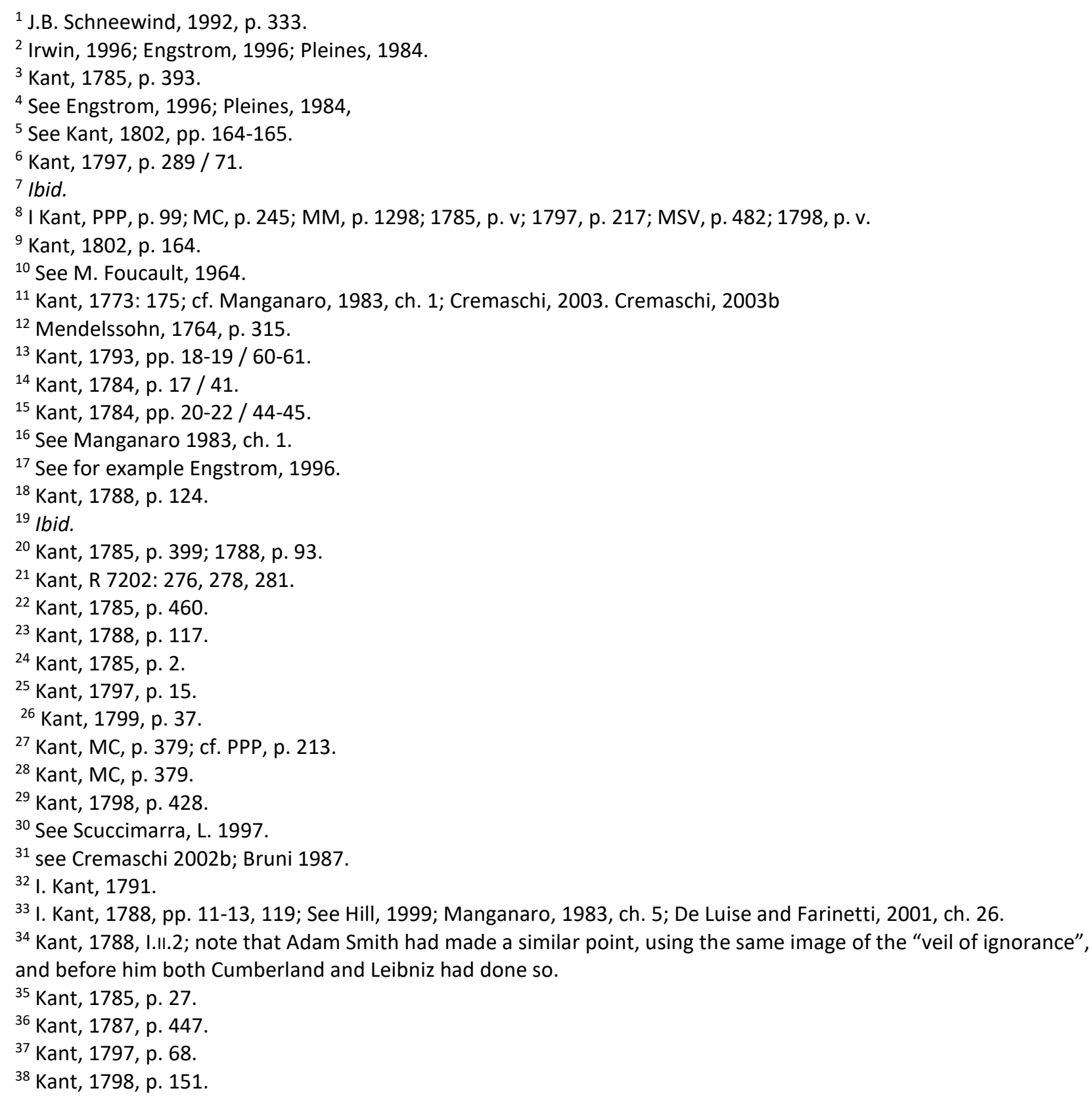


${ }^{39}$ See Cremaschi, 2002.

${ }^{40}$ See Cremaschi, 1989.

${ }^{41}$ Kant, 1785, p. 395.

42 Ibid.

${ }^{43}$ Kant, 1784, pp. 27-28 / 50-51.

${ }^{44}$ Kant 1784, pp. 24-26 / 47-49.

${ }^{45}$ Smith, 1759, IV.I.10; cf. Bruni, 1987.

${ }^{46}$ See Smith, 1776, IV.IX.16-17.

47 See Smith, 1759, VI.II.II-III.

${ }^{48}$ see Cremaschi, 1984, ch. 4; 1989.

${ }^{49}$ Cf. Hirschman, 1977; Bruni, 1987.

${ }^{50}$ cf. Manganaro, 1983, ch. 2; Bruni, 1987.

${ }^{51}$ Kant 1797, p. 278.

52 Kant, 1797, p. 282. 